\title{
Symbolic revolutions. Mobilizing a neglected Bourdieusian concept for historical sociology
}

\author{
Martin Petzke ${ }^{1}$ (D)
}

Accepted: 6 October 2021 / Published online: 18 October 2021

(C) The Author(s) 2021

\begin{abstract}
The article builds on a recent literature that has sought to underscore the relevance of Bourdieu's field theory for historical-sociological analysis. It draws attention to symbolic revolutions, a concept that has been given short shrift in this literature and even in Bourdieu's own expositions of his field-theoretical apparatus. The article argues that symbolic revolutions denote a universal mechanism of field-internal change which extends and complements a conceptual battery of mostly structural universals of fields. In a synoptic reading of Bourdieu's field-theoretical work, the article fleshes out an ideal type of symbolic revolutions, with special regard to its dialectical features. It adds further analytical purchase to the concept by highlighting continuities and parallels with the work of Thomas Kuhn and Karl Mannheim. Finally, it argues that more recent studies by other authors on transformations in the psychiatric field, the field of social and human sciences, and the political field are in fact discussing instances of symbolic revolutions. It thus shows how the concept can help identify common properties among highly heterogeneous phenomena, opening up new avenues for historical-sociological investigations that can more systematically relate the general and the particular.
\end{abstract}

Keywords Bourdieu · Field dynamics · Field theory $\cdot$ Historical sociology · Revolutions $\cdot$ Social change

Historical sociologists have more recently discovered Pierre Bourdieu as a "theorist of change" (Gorski, 2013a; see Calhoun, 2013; Fowler, 2020; Gorski, 2013b; Steinmetz, 2011, 2018). Countering a prevalent impression that Bourdieu's framework stands above all for social reproduction and stability, such authors have emphasized that Bourdieu's central concepts of field, habitus, and capital in fact lend themselves to analyses of sociocultural transformation. Indeed, they are "inherently historical" (Steinmetz, 2018, p. 607).

Martin Petzke

Martin.petzke@uni-bielefeld.de

1 Faculty of Sociology, Bielefeld University, Universitätsstr. 25, 33615 Bielefeld, Germany 
Much of this novel interest in Bourdieu as a historical sociologist has focused on his theory of fields. Indeed, it is perhaps here where the dynamic nature of the concept is most obvious. Fields are understood as autonomous arenas of practice in which actors vie for the dominant and hence legitimate definition of practice. What is great art? What makes a good sociologist? Such questions are permanently contested. Actors seek to impose their specific endowments as insignia of legitimacy, i.e., the "capital" of the field. This is a source of constant change: challengers displace the dominant; newcomers make a name for themselves in forging new positions or field-specific productions; and measures of field-specific worth are continually recalibrated.

While discussions seeking to instate Bourdieu as a historical sociologist have drawn attention to such change in fields on an exegetical level, empirical analyses employing the field concept have dealt with these internal dynamics to a much lesser degree. Historical sociology has thus far used field theory either in comparative work, focusing on two different states of a field in time rather than on a process (e.g., Berling, 2012; Go, 2008), or it has put most of its focus on the genesis and autonomization of fields (Chalaby, 1998; Dezalay \& Garth, 2006; Dromi, 2016; Ferguson, 1998; Krause, 2014; Sapiro, 2016; Strand, 2015). Where studies of fields do focus on internal transformations, their accounts of such change become less theorydriven and only cursorily reference field-theoretical concepts (e.g., Krause, 2011; Strand, 2011). A recent mobilization of Bourdieusian field theory in the study of transnational structures has moved the focus further away still from internal shifts of established fields to processes of field extension (see the contributions in Go \& Krause, 2016). And even attempts to elaborate field dynamics theoretically have dealt primarily with ways fields are carved out of the wider social space (e.g., Gorski, 2013b) or with varying properties of field structures rather than with the mechanisms that effect such variations (e.g., Krause, 2018).

The reason for this relative neglect of internal dynamics in work building on Bourdieu is likely due to the fact that the conceptual arsenal of field theory, despite its usefulness for historical analysis, seems to exclusively comprise structural components of fields. Terms such as nomos, illusio, doxa, specific capital, autonomy vs. heteronomy, orthodoxy vs. heterodoxy, etc. all point to features which, though they may be subject to change, are relatively static at any given point in history. Processes within fields, it seems, have been conceptualized far less distinctly by Bourdieu. Generally, dynamic features are denoted by more conventional and even somewhat nebulous signifiers such as "struggle," "competition," or "moves."

Yet, while Bourdieu hardly ever offered a general concept for field-internal change in introducing his theoretical arsenal, I argue that the notion of symbolic revolution serves this purpose precisely. Bourdieu employed the term only sporadically and mostly in passing, though it also forms part of the title of his lectures on Manet (Bourdieu, 2017). However, as a synoptic reading of his field-theoretical work shows, the conceptual relevance of symbolic revolutions is on par with his more widely recognized universals of fields.

To be sure, isolated instances of what can be identified as a symbolic revolution have been previously acknowledged by the same authors who have expounded the inherent historicism of the field concept. Fowler (2020, pp. 450-453) and Steinmetz 
(2018, p. 612) discuss Manet's intervention in the field of art as a "symbolic revolution." And Gorski (2013a, pp. 9-10) points to Bourdieu's description of Heidegger's and Flaubert's "coups" in the field of philosophy and art, respectively, to likewise drive home his point that Bourdieu must be counted among the historical sociologists. Yet, these accounts simply offer recapitulations of particular episodes of change. A clear distillation and exposition of the general and abstract features of a symbolic revolution are as yet missing, even in Bourdieu's own work.

Only through delineating such general features of symbolic revolutions do we gain further analytical purchase on "universal mechanisms" of fields (Bourdieu, 1993, p. 72). Therein lies the strength of field theory, which moves us "beyond the deadly antinomy of monographic idiography and formal, empty theory" (Bourdieu, 1993, p. 72). It is at its core a comparative endeavor, constantly oscillating between generalization and respecification. Invariant properties of fields are distilled out of iterative comparisons of fields understood as "particular cases of the possible" (Bourdieu, 1995, p. 182; Bourdieu \& Wacquant, 1992, p. 233; see Bachelard, 1949). The "methodical transfer of general concepts and problems" (Bourdieu, 1995, p. 182) then allows for specific analyses that resituate the singular field in its historical context - a context which can account for the particular appearance or even lack of otherwise common features.

A contoured concept of "symbolic revolutions" can thus add to this heuristic arsenal and enhance our understanding of general properties of fields. Moreover, it can complement an armamentarium of concepts relating mostly to structural components of fields with a concept that elaborately captures a general dynamic within fields. Such a concept would prevent historical-sociological analyses of fields from falling back upon the purely historiographic whenever they turn to transformations within fields. It can further accentuate the abstract dimension of field-theory in such investigations while still accounting for the particular and concrete, precisely in ways envisioned not only by Bourdieu, but also by Weber (1949), who himself sought to overcome the dichotomy between nomothetic analysis and idiographic description (for a "critical realist" plea to the same effect see Steinmetz, 2004). The concept of "symbolic revolutions" is thus capable of serving a similar function as the term "rationalization" in Weber's work (though without the attendant implication of an occidental master trend): it allows comparing and, more importantly, in the first place finding similar transformative processes in highly heterogeneous spheres while simultaneously paying heed to the specifics and contingencies of each particular case (e.g., Weber, 1946). In so doing, it can help ascertain the individual causes of a case's "being historically so and not otherwise" while still drawing on notions of "recurrent causal sequences," albeit considered in unique configurations (Weber, 1949, pp. 72, 79; his italics).

In the following, I flesh out an ideal type of a symbolic revolution through a synoptic reading of Bourdieu's various work on social fields. I show that most of his descriptions of fields feature an instance of a symbolic revolution and nearly all of them follow a very circumscribed conjunctural logic. I then proceed to shed some light on the intellectual origins of this notion of symbolic revolution, which I trace back to Thomas Kuhn and to Karl Mannheim. As I show, the parallelization with Thomas Kuhn and his distinction between normal science and scientific revolutions 
can help distinguish different forms of change that are often conflated in the reception of Bourdieu's work (and occasionally by Bourdieu himself). The parallelization with Mannheim, on the other hand, demonstrates that the distinctly dialectical form of cultural change as it is captured by the concept of symbolic revolutions has a significant precedent in classical sociology of knowledge, an apparent intellectual indebtedness that, however, Bourdieu did not explicitly acknowledge. Finally, in discussing three recent studies by other authors on the psychiatric field, the field of social and human sciences, and the political field, I show how the concept of symbolic revolutions can conceptually highlight similarities and parallels among transformations in various fields that otherwise remain obscure. Mobilizing this concept is thus crucial in further elaborating a theoretical language of change. It can abductively orient the iterative process of comparing various instances of transformation across heterogeneous fields with an eye to identifying common mechanisms and properties.

\section{Symbolic revolutions - an ideal type}

Throughout his various studies of fields, Bourdieu often describes particular instances of symbolic revolutions that share certain general features. Not all of them are explicitly designated as "symbolic revolutions" and not all of them exhibit all features at once, at least not in their depiction. Yet, a synoptic reading allows for the construction of an ideal type of a symbolic revolution that can then be respecified in employing the construct empirically. Thus, Bourdieu's own comparative approach to field theory is here taken to an exegetical level. In attending to the "structural and functional homologies" (Bourdieu, 1995, p. 182) between fields as he describes them, such a reading can identify common and general features of Bourdieu's understanding of symbolic revolutions while granting that each of the described instances, like his fields more generally, "delivers more or less clearly the properties it shares with all the others." To be clear, then, what follows is not simply a compilation of all instances where Bourdieu deals with symbolic revolutions. It is the result of an iterative reading and re-reading that compares depictions of change in Bourdieu's work in order to identify generalizable features of a very particular type of transformation.

The general properties of an ideal-typical symbolic revolution are delineated in the following and comprise 1) a conciliation of opposites; 2) a cleft habitus of symbolic revolutionaries; 3) crises as catalysts of symbolic revolutions; and 4) a return to, and remarshaling of, canonical sources within the field.

\section{Reconciling the irreconcilable: symbolic revolutions as dialectical syntheses}

Bourdieu sees fields as structured by relations of authority dividing the field into dominant and dominated poles. Such social antagonisms have their symbolic counterpart in cognitive structures through which they are perceived, evaluated and, indeed, in the first place constituted. These cognitive structures are anchored in "major obligatory pairs of opposites" (Bourdieu, 2000a, p. 100), i.e., semantic 
classifications which mark all positions and position-takings (in the form of fieldspecific productions). In forming the "principle of vision and division," or the "nomos" of the field, these categories integrate the field even as they establish its fundamental antagonisms. They separate the thinkable from the unthinkable as they delimit field-internal disputes to very specific alternatives. "Progressivism" vs. "conservatism" in politics (Bourdieu, 1992, p. 185), "gifted brilliance" vs. "earnest erudition" in the educational field (Bourdieu, 1996, pp. 14-15), or "theory" vs. "methodology" in the field of social science (Bourdieu \& Wacquant, 1992, p. 225) - these are just some examples of the "recurrent major oppositions, often condensed into antithetical terms" (Bourdieu, 2000a, p. 30), which structure the competition and contestations within the respective fields and allocate different forms of symbolic capital.

Such dualisms are so deep-seated and commanding that they in fact render controversies in the field stagnant even as they constantly set in motion struggle. As Bourdieu (2002, p. 91) holds with regard to the dualism of gender, they exhibit a "permanence in and through change." Thus, in the scientific field (as elsewhere) they can operate as "epistemological obstacles," inhibiting genuine innovations that break with the shared doxa in the field and out of the conventional universe of discourse (Bourdieu \& Wacquant, 1992, p. 181).

Symbolic revolutions are the rare cases in which such established antagonisms are overturned. They inaugurate a new orthodoxy that coincides with the installation of a new "nomos," i.e., a new principle of vision and division that reorders the perceptions of legitimate practice and valuable assets in the field. Such revolutions may grant a new autonomy to the field so that one may speak of the revolution as akin to a founding act. However, they can also occur in well-established fields and simply install conceptually new distinctions that fundamentally restructure the ways in which authority and legitimacy is assigned.

Crucially, Bourdieu consistently describes such symbolic revolutions as dialectical syntheses between opposite poles, i.e., between opposed forms of practice in the field and thus between the corresponding obligatory pairs of opposites. Formerly irreconcilable antinomies and antagonisms are reconciled in a Hegelian maneuver of sublation (Aufhebung), as it were, in which both poles are simultaneously rejected and preserved. It is this conciliation of opposites that is most unique to symbolic revolutions as a form of field-internal change. It is also a feature that has been consistently missing in previous discussions of the concept of "symbolic revolutions" (e.g., Fowler, 2020). Yet, as a comparative reading of Bourdieu's field-theoretical work can show, examples of such dialectical syntheses can be found in the most heterogeneous of fields.

Bourdieu gives perhaps the clearest example of this in the field of art and ties it to the names of Edouard Manet in the field of painting, Gustave Flaubert in the literary field, and Charles Baudelaire in the lyrical field. Bourdieu's fundamental argument that these men created new and homologous positions that gave the field of art its modern autonomy is of course widely acknowledged, especially among those who seek to claim Bourdieu as a historical sociologist. Yet, the dialectical nature of each of their maneuvers as Bourdieu portrays them has been far less appreciated, if at all. All three, Manet, Baudelaire, and Flaubert synthesized 
antipodean forms of aesthetic practice in the field of art as it presented itself to them at the time.

In the field of painting, the orthodoxy of the Académie française with its canonical hierarchies of classical subject matters stood opposed to realism, which profaned such hierarchies in genre paintings that turned to the vulgar and common. Manet created a third position. Like realism, he turned against the academy by participating in the profane act of making the real life of modernity his subject. Yet he also opposed realism, which still adhered to the academy's fundamental logic of composition: Through such techniques as chiaroscuro, the human subject in realist paintings was cast in a morally validating light. In this, realism continued to follow narrative norms of the academic orthodoxy. In a double rejection, Manet not only turns to quotidian subject matters (against the academy) but also entirely eliminates perspective and narrative (against realism). With an aesthetically "pantheistic outlook" (Bourdieu, 2017, p. 197), Manet accords equal value to all elements of the painting and thus reinstates the two-dimensional as its authoritative domain. Crucially, this creates new compositional problems, for which Manet adopts and re-enlists techniques of the old masters canonized by the academy. By virtue of this coup, Manet reconciles the fundamental antagonism of academic orthodoxy and realism at the same time as he subverts it. In so doing, he creates a new dominant position that reshuffles and realigns all other positions in the fields. The fundamental synthesis that simultaneously nods to and disavows both the academy and realism is condensed in the formula of "Manet borrow[ing] Velázquez's technique in order to paint a subject that was real and contemporary" (Bourdieu, 2017, p. 330-331).

In the literary field, Gustave Flaubert launched a similar symbolic revolution in an analogous move to "reconcile the irreconcilable" (Bourdieu, 1995, p. 77). He presented an aesthetic program of "writ[ing] the mediocre well" (Bourdieu, 1995, p. 94), which again encapsulates the dialectical nature of the position he was creating. It both negated and preserved the established opposition of the lyricism of pure form, embodied by Gautier, and the realism of the quotidian and ordinary, personified by Champfleury. His style was a "blend [of] lyricism and the vulgar" (Bourdieu, 1995, p. 96).

And in the subfield of lyricism itself, Baudelaire accomplishes a symbolic revolution of his own in reconciling the fundamental opposition of form and substance, formalism and realism. His third way is a call for "pure work on pure form...that causes to surge up...a real more real than that which is offered directly to the senses" (Bourdieu, 1995, p. 107). It is a gaze that privileges form while still attending to the real, not for its moral and political implications but for its aesthetic essence.

Even in his analysis of the comparatively materialistic world of the French house economy, Bourdieu (2005) describes a full-fledged case of a symbolic revolution. Here, the field of the house market had previously been structured by an antagonism of "technical 'strengths", vs. "symbolic 'strengths,", pitting industrial procedures of mass production against traditional masonry (Bourdieu, 2005, p. 58). A synthesizing maneuver establishing a third way of production led to a "breakdown of this equilibrium" (Bourdieu, 2005, p. 58). In resorting to massive sub-contracting of small builders, some companies again succeeded in "reconciling previously irreconcilable elements: the technical advantages of mass production and the symbolic advantages 
of craft manufacture" (Bourdieu, 2005, pp. 58-59). Such firms, "industrially [manufacturing] products that are traditional in appearance," (Bourdieu, 2005, p. 49) created a newly dominant position in subverting an established opposition through a dialectical move of negating and preserving elements of both opposites.

In the intellectual field, Bourdieu (1980) considers Sartre a symbolic revolutionary. Again, the latter was able to achieve dominance through a "coup de force" that "brought together a set of hitherto separate ways of filling the role of intellectual" (Bourdieu, 1980, p. 11). Sartre invented the "total intellectual" who was philosopher, critic, novelist, and dramatist at once. In so doing, he relegated all others to subordinate positions in the field: Merleau-Ponty, who had now become only a philosopher; Camus, thus turned into nothing but a novelist; Blanchot, now no more than a critic; Bataille, a mere essayist; and Aron, disqualified as just a sociologist and political scientist. In drawing together all positions at once, Sartre bridges the divide between professors, philosophers, and critics on the one side and writers on the other side: "Philosophy takes to the streets and the philosopher, like the literary man, writes at café tables" (Bourdieu, 1980, p. 11).

In his work "The Political Ontology of Martin Heidegger," Bourdieu (1991) in fact describes two symbolic revolutions, one in the field of political ideologies in the Weimar Republic, the other in the philosophical field, where Heidegger is able to translate the ideological revolution into a philosophical one.

In the field of political ideologies, people like Oswald Spengler or Ernst Jünger again followed a "third-way strategy" (Bourdieu, 1991, p. 29) in synthesizing the opposition of liberalism and socialism, capitalism and Marxism. Jünger "reconciled the cult of the people (Volk) with the aristocratic hatred of the "masses" (Bourdieu, 1991, p. 31). Intellectual maneuvers such as his carved out a third ideological position that rejected both the economic elitism of the liberal bourgeoisie and the uniformity and anonymity of the socialist mob. In negating both poles, elements of both were again simultaneously preserved: The anti-bourgeois populism of socialism was married to an elitism of its own kind, a mystical heroism of authentic Germanness which culminated in the concept of the Führer (Bourdieu, 1991, p. 31).

It is precisely this symbolic revolution that Heidegger invites into the philosophical field but transfigured by the field's own antagonisms. Here, Heidegger sees himself confronted by the opposition of neo-Kantianism and historicism, of universal reason and historicity, a division resonating with the opposition of liberalism and socialism in the field of political ideologies. Heidegger's "ontologization of the transcendental" (Bourdieu, 1991, p. 66) is again a revolutionary move that at once rejects and preserves elements of both opposites. In equating being and time, thus "by asserting the essential historicity of the existing, and by inscribing history and temporality within being, that is, within the ahistorical and the eternal," he is able to elude historicism at the same time as he dethrones neo-Kantianism's authority of reason in favor of intuition. His revolution also intervenes in the internecine antagonisms of "the neo-Kantian problematic" itself, represented by Cohen on the one side and Husserl's phenomenology on the other (Bourdieu, 1991, p. 58). Like the realist Courbet in the field of painting, who rejected the hierarchies of subject matters but stuck to the narrative conventions of the academy, Husserl's own revolution had only gone 
halfway: He recognized the role of time in perception but fell short of subverting the authoritative role of reason (Bourdieu, 1991, p. 61). Like Manet, Heidegger brings this "partial revolution" (Bourdieu, 2017, p. 408) to its completion in "disclosing the existential finitude at the heart of the Transcendental Aesthetic" (Bourdieu, 2008, p. 102).

It is a maneuver resonant with the conservative revolution in the political field. In fact, to Bourdieu it is a euphemistic transfiguration of the latter, given its similar evocations of anti-enlightenment "irrationalism" and the elitism of an "authentic being" (Bourdieu, 1991, pp. 67, 78-79). Heidegger thus "produces a previously impossible philosophical position, which is situated in relation to Marxism and neo-Kantianism in the way that the 'conservative revolutionaries' are situated in the ideologico-political field in relation to the socialists and the liberals" (Bourdieu, 1991, p. 69).

Finally, Bourdieu clearly understood his own contribution to sociology as a "conciliation of contraries" (see Bourdieu, 2008, p. 102) in the sociological field. It lies first and foremost in his "synthesis" of the "opposition between theorists and empiricists" (Bourdieu, 1990, p. 34), manifested for instance in the ways in which he "invested great theoretical ambitions in often at first sight trivial empirical objects" while employing "painstaking empirical work" (Bourdieu, 2008 , p. 102). A conciliation is further apparent in his "supersession of the forced choice between objectivism and subjectivism and the recourse to mediating concepts" (Bourdieu, 2008, p. 103). The latter is a synthesis, of course, that is rehashed in nearly every introductory text on Bourdieu and his notion of habitus. What is overlooked, however, are the implicit parallels Bourdieu himself draws to other symbolic revolutionaries in their respective fields.

Such parallels are laid out in the subtle comparisons he draws in his "sketch for a self-analysis" (Bourdieu, 2008). He likens his intervention in the sociological field to Heidegger's revolutionary attacks on neo-Kantianism in the philosophical field (Bourdieu, 2008, p. 102). Furthermore, he suggests that his move of simultaneously negating and incorporating all positions in the field - "in some ways, 'anti-everything,' and, from another angle, 'catch-all'" - bears at least some resemblance to Sartre's invention of the total intellectual (Bourdieu, 2008, pp. 68-69).

In summary, all the symbolic revolutions delineated above share the feature of a synthesizing move which subverts the established oppositions of the field by reconciling them in a third position. This fundamentally dialectical dimension is further evident in the various oxymora that Bourdieu employs to characterize these newly created positions in the field: "realist formalism" or "formalist realism" for Manet, Flaubert, and Baudelaire (Bourdieu, 1995, p. 107, 2017, p. 452); "mass-produc[ing] traditional houses" for organizational innovators like Maison Bouyges in the house market (Bourdieu, 2005, p. 58); "the writerphilosopher and metaphysician-novelist" for Sartre (Bourdieu, 1980, p. 11); “a (paradoxical) ontology of immanent historicity, a historicist ontology" for Heidegger (Bourdieu, 1991, p. 61); and, finally, "genetic structuralism" for his own brand of sociology (Bourdieu, 1990, p. 14). 


\section{The "cleft habitus" of symbolic revolutionaries}

"Authors of great symbolic revolutions," writes Bourdieu (2000a, p. 92), "find themselves placed before a space of already made possibles, which for them and them alone, designates in advance a possible to be made" (my italics). They are predisposed to reconcile the irreconcilable because of what Bourdieu calls their "cleft habitus" (Bourdieu, 2017, p. 297). Theirs is a habitus which is itself the product and marriage of biographical tensions and contradictions, which makes it uniquely suited to bring and hold together the opposites of a field - opposites which, after all, are often overdetermined by the same divergent class affiliations that have also left their mark on the cleft habitus. Again, the cleft habitus has been acknowledged as a source and concept of change by those who have sought to flesh out the theory of transformation inherent in Bourdieu's work (Fowler, 2020, p. 452; Steinmetz, 2018, p. 609). However, what has been overlooked is that Bourdieu consistently sees it as a subjective predisposition towards dialectical syntheses within fields. It is precisely the hybrid character of those marked by such a habitus and "the meeting of two histories" (Bourdieu, 1995, p. 256), i.e., of the field and the agent, that triggers a conciliation of opposites.

Thus, for Flaubert and Manet, Bourdieu notes that both were sons of wealthy and established families who broke with the conventional career expected of them. They were "neither bourgeois nor bohemian, but...instead both bourgeois and bohemian" (Bourdieu, 2017, p. 320). Manet, like Flaubert, had a "foot on both sides" of the field of power but did "not really feel at home" on either side (Bourdieu, 2017, p. 303). It is by virtue of a chronic feeling of being "caught between two stools" as a "bourgeois artist" that Manet was predisposed to synthesize opposite ways of artistic practice. This is a trait typical of "revolutionary characters": they are "ill at ease in both of the worlds within which they feel torn and which they subvert" (Bourdieu, 2017, p. 302).

Similarly, Bourdieu (1991, p. 48) sees Heidegger as having owed "his extraordinary position" in the philosophical field "to an awkward, strained relationship to the intellectual world," which was the product of "an improbable, and thereby all the more exceptional social trajectory." It was precisely this unique biographical path, traversing the social space from the "lesser rural petty bourgeoisie" to the position of "professor ordinarius," that again furnished him with a "gift for making connections between problems which previously existed only in fragmentary form, scattered around the political and philosophical field" (Bourdieu, 1991, p. 47).

And in his autobiographical "self-analysis," Bourdieu (2008, p. 100) notes that the tension between his "low social origin" and "high academic consecration" likewise makes for a "cleft habitus." As "the product of a "conciliation of contraries' which then inclines one to the "conciliation of contraries"' (Bourdieu, 2008, p. 102), it nourished an ambivalence towards the academic field that predisposed him to the type of double rejection and double preservation - the "neither-nor" and "as well as" - that marks all symbolic revolutions. 


\section{Crises as catalysts of symbolic revolutions}

As the last subchapter has made clear, symbolic revolutions are the result of the meeting of two histories: the biographical history of a "cleft habitus" with a predisposition to reconcile the irreconcilable, and the history of a field structured by opposites that are "ripe" for reconciliation. But how can the structure and history of a field open up such avenues for symbolic revolutionaries to overturn extant dualisms in a newly dominant synthesis? Most of the revolutions Bourdieu describes are precipitated by a fundamental social crisis or disruptive shift impacting (and refracted by) the field in question. Such crises are prone to undermine a field's theretofore unquestioned orthodoxy in eroding its legitimacy. Perhaps more fundamentally, however, crises disrupt the taken-for-granted quality of the obligatory pairs of opposites in the field in "breaking the immediate fit between the subjective structures and the objective structures" (Bourdieu, 1977, pp. 168-169). With the "doxa" (ibid.) of such perfect correspondence no longer intact, previously undiscussed and obscured third options can appear on the horizon as possibilities ready to be realized by those with the proper dispositions. No less importantly, however, such previously unthinkable options also become feasible to a wide audience within and outside the field once their "doxic relation to the social world" (Bourdieu, 1977, p. 168) has been shaken. Thus, crises leading to symbolic revolutions are most often of a broader nature, affecting social space as a whole, so that subversive strategies are likely to be reinforced by "external forces" such as the emergence of "new clienteles" for novel forms of practice (Bourdieu, 1995, p. 234).

For the field of art, Bourdieu (2017) shows how the expansion of the educational system produced a surplus of graduates, which, given that the arts have a comparatively low threshold for entry, went along with a surplus of those aspiring to become an artist. As a result, the growing number of rejects from the academy brought new pressures to bear on the field. It led to the emergence of several alternative schools of painting and, eventually, also to alternative venues of exhibition (such as the Salon des refusés). All of this produced "a generalized crisis of belief" in the hitherto unquestioned legitimacy of the academy and the distinctions and oppositions that had previously organized the field (Bourdieu, 2017, p. 151). These developments created a broad audience of artists and aesthetes in and outside the field who, given their resentment towards the academy and their loss of faith in the established aesthetic taxonomies, were highly receptive to the radical innovations of Manet.

For the house market, Bourdieu (2005) likewise highlights a fundamental crisis that enabled the rise to dominance of the organizational innovators who combined industrial norms of mass-production with traditional norms of masonry. An economic recession in the 1980 s adversely and disproportionately affected large corporations who were using industrial techniques in mass-producing houses affordable to lower-income costumers (Bourdieu, 2005, p. 51). The crisis substantially re-enhanced the standing of traditional masonry in the field given that firms in that sector had always courted a wealthier clientele and were now better able to weather an economic recession. It thus created an opportunity for the decisive innovation of combining industrial scale production with the adherence to aesthetic norms of craft manufacture through sub-contracting and franchising. 
In his short account of Sartre's revolution in the intellectual field, Bourdieu (1980, p. 12) similarly suggests that the "crises" and "traumas" of the German occupation, the résistance, the liberation, and the "sense of breakdown" that went along with it produced "a social demand for intellectual prophecy" that paved Sartre's road to dominance in the intellectual field.

And prior to Heidegger's "conservative revolution" in the philosophical field, a massive influx of students produced an intellectual proletariat of teachers at the margins of the university system who saw themselves compelled to take up positions well below their academic qualification; professors experienced a decline in their social and economic status due to inflation; and the humanities were increasingly devalued in light of the rise of the natural and social sciences (Bourdieu, 1991, pp. 12-14). The dislocation of once self-evident perceptions and aspirations on the one side and the structural realities of the field on the other nourished a "völkisch mood" (Bourdieu, 1991, p. 10) among the educated bourgeoisie, a resentment-laden zeitgeist of an anti-modern, anti-democratic, anti-positivist, and even anti-intellectual bent. It again created a receptive audience for the symbolic revolution in the field of political ideologies and its euphemized variant in the philosophical field.

\section{Return to canonical sources}

Finally, many symbolic revolutions legitimate themselves through recourse to canonical and authoritative sources of the field. This again attests to the central role of a cleft habitus within the syndrome of an ideal-typical symbolic revolution. Symbolic revolutionaries are often as much a product of the field as they are at odds with it. Intimately familiar with the history and logic of their field, they marshal their competence and familiarity against the field's established structure from which they simultaneously feel alienated. Such a move goes beyond a prophetic call to pure origins which decries the corruption of the establishment. It employs the authority of the canon to subvert, rather than reinstate, the established antagonisms in what is a novel synthesis.

Thus, Manet enlisted old masters of the past, canonized by the academy, in his coup against the academy itself as he borrowed some of their formal techniques for his revolutionary compositions, drawing "on the weapons of the tradition to forge his arms against tradition." (Bourdieu, 2017, p. 463).

For Bourdieu (1991, p. 46), Heidegger, too, was able to "forge from a renewed reading of the most sacred authorities the weapons of a revolution designed to restore tradition to its original authentic form." In Heidegger's case, the canonical source was Immanuel Kant: "in revealing the metaphysics which underpins the Kantian critique of all metaphysics, Heidegger appropriates for 'foundational thinking' ... the capital of philosophical authority held by the Kantian tradition. This masterly strategy enables the neo-Kantians to be attacked, but in the name of Kantianism" (Bourdieu, 1991, p. 59).

And Bourdieu frames his own intervention in sociology in similar terms: Social science had to be rid from "a whole series of reductions and impoverishments" which were imposed by the "global orthodoxy" of Parsons, Merton, and Lazarsfeld, 
and this was to happen through Bourdieu's "return to the texts of Durkheim and Max Weber, both of whom had been annexed and distorted by Parsons" (Bourdieu, 2008 , p. 72). On the empirical end, too, Bourdieu availed himself of the statistical "instruments of the adversary and use[d] them in the service of other scientific ends" (Bourdieu, 2008, p. 73). He rejected the positivism of Lazarsfeld and his French acolytes while drawing on his own experience at the INSEE to "master the whole panoply of techniques - multivariate analysis or latent classes" but without "the scientistic baggage" (Bourdieu, 2008, p. 73).

In conclusion, the synoptic reading has furnished us with an ideal type of a symbolic revolution as a syndrome of four phenomena: 1) Symbolic revolutions synthesize the dualisms that have theretofore structured the perceptions and actions in the field. In so doing, they instate an entirely novel position which, in preserving and merging central assets and symbolic resources of each of the opposite positions, becomes the newly dominant position. It thus fundamentally reorders the standards of field-specific practice and the matrix of assigning worth and recognition in the field. 2) Such symbolic revolutions are generally brought about by agents with a "cleft habitus." Marked by contradictory belongings and improbable trajectories, such agents can in many ways be seen as an incarnation of (often multiple) dialectical syntheses. They thus have a unique capability and indeed predisposition to marry seemingly irreconcilable opposites in the field. 3) Symbolic revolutions generally occur where agents with such predispositions encounter fields that have been disrupted by crises. Here, the self-evident quality of the obligatory pairs of opposites that had hitherto relegated third options to the realm of the unthinkable dissipates and the established dualisms become questionable. The increasing dislocation of the structures of perception and the structures of the field prepare an audience for an intervention that ushers in a revolutionary form of field-specific practice. (4) Finally, such interventions generally invoke canonical figures and sources of the field which they paradoxically enlist in subverting the field's established antagonisms. The cleft habitus of the revolutionaries, deeply immersed yet never fully at home in the field, tends to marshal a substantial expertise acquired in the field against the field.

How can symbolic revolutions be distinguished from other forms of change in fields generally characterized by constant struggle? And whence the central feature of dialectical synthesis in this idea of fundamental transformation? As I show in the following, inquiring into the intellectual origins of the concept of symbolic revolutions can shed additional light on these questions. It can further elucidate how this mechanism can be employed to theorize and distinguish change within fields.

\section{On the intellectual genealogy of the concept of symbolic revolutions}

Two authors seem to have been especially influential with regard to Bourdieu's concept of symbolic revolutions. One of them is Thomas Kuhn, whose concept of paradigm change Bourdieu himself occasionally compares to symbolic revolutions. The other is Karl Mannheim, who, curiously, is not invoked in this context but whose essay on "Competition as a Cultural Phenomenon" delineates precisely the form of dialectical change captured by Bourdieu's concept of "symbolic revolutions." While 
a closer look at Kuhn as a source of inspiration can offer some insights on how symbolic revolutions can best be distinguished from other forms of field-internal change, the interrogation of Mannheim will show that perhaps the most curious and indeed most overlooked feature of symbolic revolutions - the dialectical synthesis of opposites in the field - indeed has a prominent guarantor among the classical sociologists.

\section{Symbolic revolutions as paradigm change - Kuhnian connections}

On occasion, Bourdieu draws parallels between symbolic revolutions and paradigm change as described in Thomas Kuhn's “The Structure of Scientific Revolutions," specifically in invoking Manet (see Bourdieu, 2000a, pp. 100-101, 2004, p. 16,2017 , p. 244). Indeed, what is overthrown in symbolic revolutions as much as in paradigm change is a specific "disciplinary matrix" (Bourdieu, 2000a, p. 100; Kuhn, 1970, p. 182). In fields, such a matrix consists of the "major obligatory pairs of opposites" (Bourdieu, 2000a, pp. 100-101), examples of which were discussed above: academic art vs. realism; industrial production vs. traditional masonry; liberalism vs. socialism; subjectivism vs. objectivism, etc. They structure perceptions, evaluations, and moves of all actors within the field even as they pit them against one another. As we have seen, precisely these opposites are subverted in symbolic revolutions, which establish fundamentally new ways of perceiving, evaluating, and acting. In this sense, symbolic revolutions usher in a new paradigm, incommensurable to the previous one.

However, the parallels between Kuhn's scientific revolutions and Bourdieu's symbolic revolutions do not end there. Kuhn, of course, himself alerts to the crucial role of crises in undermining an established paradigm, setting it up for subversion. At such critical junctures, the paradigm is not only threatened by anomalies for which conventional scientific wisdom cannot account. For Kuhn (1970, pp. 71, 80), scientific orthodoxy is also eroded by the corresponding "proliferation of versions of a theory," and with it, the "loosen[ing] of the rules of normal puzzle-solving." For the artistic field on the eve of Manet's revolution, Bourdieu paints a very similar picture: A variety of new schools of painting and new salons of exhibition emerge and increasingly chip away at the academy's authority. To be sure, however, the crises envisioned by Bourdieu are somewhat broader than those envisioned by Kuhn. Whereas from Kuhn's perspective, anomalies grow out of scientific operations themselves and crises emerge within the scientific field, for Bourdieu, such crises most often emerge outside the field with broad repercussions in social space, which are then refracted by the field's particular logics. ${ }^{1}$

Moreover, like Bourdieu, Kuhn (1970, p. 7) points to a particular type of revolutionary character with certain predispositions to accomplish paradigm change. For him, outsiders and newcomers are "almost always" the ones who are able to establish a new paradigm, precisely because they still have one foot outside the conventional game in which others are fully immersed. It is an idea resonant with

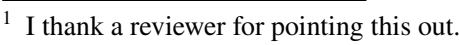


Bourdieu's notion of a cleft habitus and its ambivalent mixture of both commitment to and detachment from the poles in the field. For Kuhn (1970, p. 90), scientific revolutionaries are "men who, being little committed by prior practice to the traditional rules of normal science, are particularly likely to see that those rules no longer define a playable game and to conceive another set that can replace them."2

These affinities with Kuhn allow us to get an even firmer handle on the concept of symbolic revolutions. Extrapolating from Kuhn's distinction between normal and revolutionary science helps us distinguish between two different sets of dynamics in the field, dynamics that tend to be conflated in Bourdieu's work. ${ }^{3}$

We often find Bourdieu describing fields as being in a state of "permanent revolution" (e.g., Bourdieu, 1995, pp. 239-242). Most of these struggles, however, are in fact structured by, rather than subvert, the pairs of opposites internalized by all actors within the field. Maneuvers, including innovative positions and position-takings, normally do not undermine the fundamental antagonisms but are in line with the conventional "paradigm," as it were. Even the toppling of an established orthodoxy in the wake of a generational change can still leave the foundational matrix of opposites intact. Bourdieu (2008, p. 14; Bourdieu \& Passeron, 1967) himself writes of the field of the social sciences as he saw it in the 1960s that the "pendulum" had been merely swinging back and forth between subjectivism and objectivism (prior to his subversion of the distinction). ${ }^{4}$ In this sense, a "prophetic" challenge calling for a return to sacred sources can do so without introducing a radically new principle of legitimacy but rather in the name of a purer version of the established orthodoxy (Bourdieu, 1995, p. 299). In fact, this is an entirely different dialectic encapsulated by Weber's distinction between the priest and the prophet and the routinization of charisma, which Bourdieu draws upon to theorize intergenerational change in fields (see, e.g., Bourdieu, 1995, pp. 205-206).

Such common struggles, I argue, can be seen as the equivalent of "esoteric research" during the long stretches of "normal science" as envisioned by Kuhn (1970, pp. 23-34). It is the "further articulation and specification" (ibid., p. 23) of the paradigm, its fleshing out and conjugating, as it were. It allows for innovation, but within the confines of the "disciplinary matrix." Such incremental change is a necessary dynamic in any field, given that those entering a field must make a name for themselves, or "leave a mark" (Bourdieu, 1995, p. 154), by virtue of distinguishing themselves from extant positions. It is part of what Steinmetz (2018, p. 612) felicitously calls "the constant churning and cycling of dominant and dominated

\footnotetext{
${ }^{2}$ Bourdieu (2017, p. 302) himself points to Cohn (1970) as the source of his ideas on the cleft habitus.

${ }^{3}$ I leave out hypothetically construable forms of change that pertain less to field-internal dynamics than to the ways in which a field is carved out of social space, like variance in autonomy, size, shape, and the boundaries of the field; on this see Gorski (2013b). For an empirical example regarding the literary field's loss of autonomy in Vichy France, see Sapiro (2013). I also leave out the "limiting case" of loss of fieldedness altogether, as when fields turn into an "apparatus"; on this see Bourdieu \& Wacquant (1992, p. 102).

${ }^{4}$ On such swinging of the pendulum between fundamental disciplinary oppositions cf. also Abbott (2001).
} 
groups, with newcomers challenging and sometimes overturning hegemonic taste and the status of consecrated elites."

Symbolic revolutions differ from these regular struggles within the field in precisely the way scientific revolutions differ from the cumulative research of normal science. They instate an entirely new "world view" (Kuhn, 1970, pp. 111-135); in the case of Bourdieu's symbolic revolution, this means the overturning of the oppositions that organize the field and a fundamental restructuring of perception and practice along the lines of entirely novel antagonisms. In this relatively rare intervention, the prophetic invocation of pure origins and the installment of a revolutionary nomos, i.e., the principle of vision and division in the field, coincide in the way delineated in the previous section.

Hence, the creation of novel positions and position-takings in a field will generally only take two forms. Agents can either work within the established matrix structured by the obligatory pairs of opposites and establish a distinctive, even epochal and generationally defining position for themselves without radically altering the fundamental dualisms of the field. Or, more rarely, they can entirely overturn such dualisms in the dialectical synthesis that is a symbolic revolution. However, innovations will generally have to go one route or the other. They cannot emerge "ex nihilo" or from outside the field without disqualifying themselves as "naïe" at the same time (Bourdieu, 1995, pp. 242-244): membership in the field presupposes a practical mastery of the history of the field and the "space of possibles." For a move to be perceived as competent and grammatically correct, it will thus necessarily have to build on the obligatory pairs of opposites constituting the fields' "current problematic" (ibid.) This holds true even for the latter's subversion, which, as a double rejection of both opposites, is thus prone to take the form of a synthesis.

In sum, by way of aligning Bourdieu's theory of symbolic revolutions more closely with Kuhn's distinction of normal science and "paradigm change" - an alignment justified by the affinities between both notions -, Bourdieu's "permanent revolutions," fueled by the logic of distinctive positions and position-takings and the dialectics of establishment and newcomers, can be more systematically distinguished from the more fundamental dialectical change effected by symbolic revolutions.

\section{Symbolic revolutions as syntheses - Mannheimian connections}

Thomas Kuhn's scientific revolutions, however, do not mention any form of reconciliation of opposites. Where, then, does the perhaps most striking and in fact universal feature of Bourdieu's symbolic revolutions, the dialectical synthesis, stem from? Despite his indebtedness to Marx, I argue that for Bourdieu the central source of this dialectical pattern is Karl Mannheim. Bourdieu only rarely mentions Mannheim in his work and never in the context of symbolic revolutions. He is most often discussed and criticized for his notion of the rootless, free-floating intellectual (Bourdieu, 2000a, p. 131, 2020, p. 251; Bourdieu et al., 1991, p. 74). Yet, the parallels between Bourdieu's sociology and Mannheim's sociology of knowledge are obvious. 
The affinities are perhaps most striking when it comes to Mannheim's (1952) article "Competition as a Cultural Phenomenon." The text presents social competition as crucial co-determinant of the shape and content of cultural creations and ideas. More pertinently to our present discussion, however, it gives a "sociological interpretation of dialectics" (ibid., p. 228), tracing it back to generational change and competition. It is precisely here where we find a mechanism of cultural change almost identical to the dialectics exhibited by "symbolic revolutions."

Like Bourdieu, Mannheim assumes that groups are vying "for the correct social diagnosis" (Mannheim, 1952, p. 196), aiming to gain power and recognition in imposing their view of the world as the legitimate one. In premodern societies, such competition was limited. Only with increasing social differentiation does society enter a stage of "atomized" and "multipolar" competition in intellectual life. However, as "doctrinal currents" (ibid., p. 208) touch viewpoints in different regions throughout an increasingly interdependent social world, competition becomes more concentrated. Thus, for Mannheim, the dominant type of competition today is that between polarized extremes, such as between conservative and progressive thought.

Crucially, for Mannheim such polarization opens up the possibility of synthesis. In fact, the philosophical edifice of Hegel, the "discoverer of dialectics," was in itself a synthesis between two opposing ideas: "the thought of Enlightenment with its absolutist bent, and the thought of conservative Romanticism and Historicism, oriented towards the phenomenon of historical change" (Mannheim, 1952, p. 223). As we have seen, Bourdieu attributed a substantively very similar conciliation of opposites to Heidegger. For Mannheim, it was no coincidence that Hegel of all came up with dialectics: "[H]e and his time for the first time in history experienced a period of strict polarization (as a result of competition at the stage of concentration), followed by a short phase of freedom of decision, issuing in the first overall synthesis" (ibid., p. 224). Thus, Hegel simply discovered his time's fundamental mechanism of competition among ideas and with it the operating principle of his own mind. Part of this synthesizing mechanism is generational change and a certain detachment from both polar extremes of the struggle, aspects that are no less central to symbolic revolutions as Bourdieu pictures them:

"There are periods in modern history during which a representative generation becomes free to achieve a synthesis. Such generations take a fresh approach in that they are able to envisage from the higher platform of a synthesis those alternatives and antagonisms which their fathers had interpreted in a dogmatic, absolute sense...[T]he old antagonisms...become less sharp, and it will be possible to find a point, so to speak, farther back, from which partisan positions can be seen as merely partial and relative, and thus transcended" (Mannheim, 1952, p. 224).

Thus, Bourdieu in fact seems to have adopted Mannheim's ideas on the ways in which modern forms of competition shape evolution in the realm of cultural creations through polarization, detachment, and synthesis. While Mannheim treated this mechanism on the level of society as a whole, Bourdieu articulated it with his theoretical framework of fields as relatively autonomous and specific arenas of competition and cultural production. The concept of symbolic revolution understood as a 
dialectical synthesis of polarized cultural positions thus has a significant precedent in the sociological canon.

\section{Mobilizing the concept of symbolic revolutions for historical sociology}

The comparative reading of Bourdieu's field-theoretical work (and the work of Kuhn and Mannheim) has provided us with a conceptual tool which can orient comparisons of what at first glance seem to be entirely heterogeneous empirical processes. The concept of symbolic revolutions, like the concept of field as a whole, thus "enables us to grasp particularity within generality and generality within particularity" (Bourdieu \& Wacquant, 1992, p. 75). Through the conceptual lens of "symbolic revolutions," various developments which have hitherto been analyzed as individual instances can now be seen as "particular cases of the possible." Training the eye on common properties and differences of such transformations can help further elaborate a general theory of change in fields.

I would like to give an example of this by drawing together three more recent studies each of which discusses a particular episode of change in a field. As I show, even just with the information provided by the authors, each episode can be recast as a particular instance of a symbolic revolution in the sense developed above. The concept can thus highlight parallels and similarities in the most heterogeneous of fields.

The first study is Michael Strand's (2011) investigation of the emergence of the DSM-III diagnostic manual in the psychiatric field. Strand describes a field that was structured by an antagonism of psychoanalysis vs. clinical psychologists, with psychiatrists originally holding jurisdiction over psychoanalytic therapy. The established dominance of psychoanalysis was undermined by the onset of a crisis: A "deinstitutionalization" of long-term treatment in inpatient facilities and the rise of community mental health policies led to a surge in demand for briefer forms of therapy that could no longer be met by the population of licensed analysts. Outside of closed facilities, the relative inefficacy of psychoanalytical forms of treatment became more apparent. The rise of third-party payers additionally diminished the standing of psychoanalysis as its procedures increasingly came to be seen as an unjustifiable drain on resources. And a broad cultural critique of the ways in which psychiatry defined and indeed constructed mental illness added further discredit to the practice of psychoanalysis.

With the dominance of psychoanalysis thus weakened, Robert Spitzer, a trained analyst from the Columbia University Institute, and his task force drafted the diagnostic manual DSM-III which was to establish a new dominant position of diagnostic psychiatry in the field of mental health. The way Strand (2011) describes Spitzer's intervention has all the hallmarks of a dialectical synthesis. The central antagonism between psychoanalysis and clinical psychology was structured by the dualism of "theory" vs. "empiricism" (Strand, 2011, p. 296). Psychoanalysis was centered upon a theory of psychodynamics and an etiological view of mental illness that signaled medical bona fides. This was opposed by clinical psychologists, who 
criticized psychiatry for labelling and pathologizing the patient instead of focusing on actual problem behaviors that could be eliminated through professional guidance and lifestyle changes.

In a move of double rejection and preservation typical of symbolic revolutions as we have developed the concept here, Spitzer and his DSM-III classification reconciled both opposites (Strand, 2011, pp. 296-300). The manual classifies disorders through identifying a subset of typical symptoms in interviews with patients. Against psychoanalysis, the DSM-III thus eliminated the concern for the etiology of the disease and focused on distressful behaviors reported as pathological by the patients themselves. Against clinical psychology, the DSM-III nonetheless held fast to the notion of disease as a dysfunction behind various clusters of problematic behaviors. Consequently, the DSM-III simultaneously preserved elements of both opposites: the medical ambition of diagnosing types of illnesses on the one side and the behavioral concerns with subjective distress and the management (and ultimate elimination) of symptoms on the other. Or in Strand's (2011, p. 296, his italics) own words: "[S]ituated between psychoanalysis and clinical psychology, or between theory and empiricism, [diagnostic] psychiatry would concentrate on form...From his critiques of psychoanalysis and clinical psychology, Spitzer bootstrapped psychiatry into a position on clinical practice, finding an interest in a specific kind of classification, now revealed as the ideal model for mental health treatment."

The second example is George Steinmetz's (2009) characterization of Max Weber's intervention in the field of social and human sciences in Germany in the late 19 th and early twentieth century. In Steinmetz's (2009, p. 96) account, the field was structured by a division of "various historicisms codified as Geisteswissenschaften" on the one side and an "array of positivisms and naturalisms that denied any difference between the natural and human sciences" on the other. This opposition, which Steinmetz, in following Ringer (1969), dubs the antagonism of "mandarins" and "modernists," was structured by such pairs of opposites as "interpretative description" vs. "causal explanation," "the idiographic" vs. "the nomothetic," "classical antiquity" vs. "modern society," and "generalism" vs. "specialization." According to Steinmetz (2009, p. 97), Weber intervened in this field with "a rather consistent pattern ... of seeking a middle-ground position between the modernist and mandarin positions," or what again may be termed a dialectical synthesis of both opposites. Steinmetz points to Weber's Habilitation thesis, which used comparative methods in analyzing the classic problem of Rome's decline, his epistemological writings, which synthesized idiography and nomothetic analysis (a synthesis which, as we have noted in the introduction, also informs Bourdieu's field theory), and his sociology of religion, where his classic concern with world religions led him to seek out the work of professors in modern disciplines such as geography or professors with more heterodox trajectories rather than the well-established work of the mandarins.

What is more, Steinmetz (2009, p. 96; my italics) sees Weber's intervention as the product of his "cleft habitus," which translated an ambiguous position between the educated and propertied bourgeoisie in social space into a middleground position between mandarins and modernists in the field of social and human sciences. Thus, in his description of a move that propelled Weber into a position as "the leading German sociologist during his lifetime" (ibid., p. 89), 
Steinmetz gives a full-fledged account of a symbolic revolution without use of the term. In fact, he even hints at parallels between Weber's and Flaubert's creation of a new position in their respective field (ibid., p. 97). However, as we have seen, Flaubert and Weber are just two particular cases of a much more general mechanism. The latter only becomes visible as such (in terms of seeing the general in the particular) as we extend the comparisons to other symbolic revolutions like the ones delineated above. In turn, this then allows us to more clearly apprehend the particular in the general.

The third and final case to be discussed here is Trumps electoral success of 2016, which has spawned several sociological investigations. Other than the above two studies, however, these generally do not make use of Bourdieu's field-theoretical apparatus. Yet, as I show, these accounts can be comprehensively integrated in a field-theoretical framework so as to render what can in fact be seen as a symbolic revolution in the political field.

As McQuarrie (2017) argues, the last decades have seen the Democratic party pivot away from traditional worker concerns and its support of unions in what he calls a "bipartisan consensus" on free trade, diminished labor rights, and economic growth. It has instead largely taken up the problem of minority rights as one of its signature issues (ibid., p. 5). The left vs. right divide of the political field thus had largely come to correspond with the opposition of, on the one side, a politics of redress for underrepresented and disadvantaged minorities such as Blacks, Hispanics, the LGBTQ-community, and women and, on the other side, a Republican message of meritocratic universalism which sees social inequality as caused by individual factors rather than structural disadvantages, tacitly legitimating a socioeconomic divide between white Americans and Americans of color (or what some critical sociologists have termed "laissez-faire racism" (Bobo et al., 1997), "colorblind racism" (Bonilla-Silva, 2006), or "systemic racism” (Feagin, 2006)).

However, especially in the electorally crucial "rust belt," a broad economic crisis of stagnant wages, loss of jobs, and a greater concentration of wealth within an increasingly post-industrial and global economy left the white working class disillusioned with both political options (McQuarrie, 2017).

As sociologists such as Arlie Hochschild (2016; see also Abramovitz \& McCoy, 2019; Major et al., 2018; Walley, 2017) have argued, Trump was able to capitalize on the growing "white resentment" among those who could not count themselves a traditional minority but who increasingly felt like an "endangered species" themselves in light of economic decline. Trump's ultimately successful political message can thus be reframed as a dialectical synthesis that entailed the characteristic double rejection and preservation of symbolic revolutions: It rejected the meritocratic universalism of Republican conservatism, which by then had left behind also many within the white community, and it rejected traditional minority politics of Democratic progressivism seeking to expand civil rights for Blacks, Hispanics, women, and members of the LGTBQ-community. At the same time, it preserved elements of both opposites. It merged the laissez-faire racism of the right that tacitly condones structural advantages of whites and the politics of redress of the left into a "white identity politics" (Walley, 2017, p. 233). This message of discrimination also resonated with a similar sense of beleaguerment and diminished influence among 
significant parts of the white evangelical community (Gorski, 2017; Whitehead et al., 2018). ${ }^{5}$

Moreover, Berezin's (2017) argument that Trump's background was an important factor in his resonance with a particular demographic alerts us to what can be recast as Trump's cleft habitus: He was ill at ease in his position not only in the field of politics (never having held political office) but also in the wider field of power. Trump, his Wharton credentials notwithstanding, did not belong to the professional class. Instead, he began his career "helping his father collect rents in the outer boroughs from working class tenants behind in their payments," and his Queens upbringing put him at odds with the "old money elites" of Manhattan (ibid., p. 225). These are the typical biographical contradictions which, according to Bourdieu, cultivate dispositions to "reconcile the irreconcilable."

Finally, Trump's intervention also signaled a return to canonical sources of the field typical of symbolic revolutions. His message of "Make America Great Again" invoked a "golden age nostalgia" and a narrative of pure origins, corruption, and prophetic renewal (Gorski, 2017, pp. 343, 353). More importantly, perhaps, he cast his politics of white grievance in the canonical rhetoric of civil rights, championing the "forgotten men and women" and tacitly aligning himself with the foundational idea of an incremental realization of equality in an ever-more perfect union. In so doing, he subverted a progressive agenda of minority rights in the name of minority rights, just as Manet employed techniques of the canonical masters against the guardians of the canon and just as Heidegger attacked neo-Kantians in the name of Kantianism.

As these re-readings of the three case studies show, the concept of symbolic revolutions can help identify similarities between such heterogeneous phenomena as the invention of a psychiatric manual, Weberian sociology, and Trumpian populism, recasting them as "particular cases of the possible." Resituating such a general mechanism in particular contexts can then open up entirely new questions. It is here where contingency and conjunctures reenter the picture. What made each case unique? Why, for instance, did Trump manage a "symbolic revolution" despite lacking the field-specific capital and mastery of the field's history that otherwise characterizes symbolic revolutionaries (and is evident also in the cases of Spitzer and Weber?) What does that say about the political field? Why were some revolutionaries less obviously marked by the biographical contradictions of a cleft habitus, yet still prone to a reconciliation of opposites? Why did some revolutions occur amidst a substantial and broadly ramifying crisis while in other cases such precipitating crises are not as obvious or more specific to the field as such? What does that

\footnotetext{
5 The case of Trump shows that, in the political field, two different "nomoi," or principles of vision and division, are in fact at stake: the principle of vision and division of different forms of political practice in the field, as condensed in the major obligatory pairs of opposites, and the principle of vision and division of the social world, as in the division of groups, classes, nations, minorities, the deserving vs. the undeserving poor, etc.; see Bourdieu (2000b). Trump's move is thus a twofold symbolic revolution: It creates a new position in the political field through the reconciliation of opposites; and, in so doing, it at the same time "creates" and validates a new collective in the social world, i.e., "whites" as a forgotten minority.
} 
say about the relative autonomy of the field? Such questions would not only lead to novel insights regarding the general concept of symbolic revolutions and the logics of particular fields but could also point the way to more elaborate theories of "crisis" or a "cleft habitus.",

\section{Conclusion}

This article has highlighted the central position of symbolic revolutions in the work of Bourdieu, a concept that as yet has been largely neglected in the reception and elaboration of his field theory. It has argued that even though Bourdieu himself hardly drew attention to the concept in introductions to his field-theoretical thinking, symbolic revolutions need to be seen on par with his more frequently recited battery of field-theoretical concepts such as nomos, illusion, doxa, specific capital, autonomy vs. heteronomy, and orthodoxy vs. heterodoxy. In fact, it complements these structural invariants of fields by pointing not to another field component but to a succinct mechanism of change.

In presenting this concept in the proper light, the article thus adds to a recent literature that has sought to emphasize the utility of Bourdieu's theoretical apparatus for the analytical endeavors of historical sociology. This literature has mostly focused on such aspects as field genesis and (transnational) expansion. Much of it has made the invariant structural components of fields historically pliable by treating them as variables. In contrast, the analytical instrument of symbolic revolutions is in no need of such conceptual fine-tuning. It is per se a historical-sociological concept through and through, theorizing a transformative process rather than a structure of fields.

Relating symbolic revolutions to similar notions of change in the work of Thomas Kuhn and Karl Mannheim has furnished the concept with further analytical purchase. Extrapolating from Kuhn's distinction between paradigm change and normal science, symbolic revolutions can be more clearly distinguished from the permanent revolution of the normal struggle for recognition and generational change in fields. What often presents itself as a rather murky view of field-internal dynamics in the field-theoretical work of Bourdieu and others can thus be more distinctly sorted out and classified. A recourse to Mannheim showed that dialectical synthesis as a mechanism of cultural transformation has in fact a prominent precedent in the sociology of knowledge. With his concept of symbolic revolutions, Bourdieu has essentially applied Mannheim's general observation on the ways in which competition structures change in intellectual life to his concept of fields as more circumscribed economies of cultural production.

The concept of symbolic revolutions thus provides an urgently needed instrument for field-theoretical work on historical transformations which has typically veered towards descriptive accounts of unique sequences. As the discussion and reframing

\footnotetext{
${ }^{6}$ Cf. in this regard also Fowler's (2021) discussion of the field-theoretical work by Gisèle Sapiro, whom Fowler sees as having further developed Bourdieu's theory of crisis and prophecy.
} 
of recent studies on interventions in the psychiatric field, the field of social and human sciences, and the political field has shown, the concept can more clearly reveal such developments as particular instances of a more general mechanism. It can not only guide investigations of change in fields in a more systematic fashion but also make for surprising and revelatory comparisons and generalizations. In so doing, it can help to more pronouncedly illuminate and differentiate abstract mechanisms and their concrete realizations in particular contexts and constellations.

Acknowledgements I thank the editors of Theory and Society and the anonymous reviewers for their helpful comments and suggestions.

\section{Declarations}

Conflict of interest The author declares that he has no conflict of interest.

Open Access This article is licensed under a Creative Commons Attribution 4.0 International License, which permits use, sharing, adaptation, distribution and reproduction in any medium or format, as long as you give appropriate credit to the original author(s) and the source, provide a link to the Creative Commons licence, and indicate if changes were made. The images or other third party material in this article are included in the article's Creative Commons licence, unless indicated otherwise in a credit line to the material. If material is not included in the article's Creative Commons licence and your intended use is not permitted by statutory regulation or exceeds the permitted use, you will need to obtain permission directly from the copyright holder. To view a copy of this licence, visit http://creativecommons.org/licen ses/by/4.0/.

\section{References}

Abbott, A. (2001). Chaos of disciplines. University of Chicago Press.

Abramovitz, A., \& McCoy, J. (2019). United States: Racial resentment, negative partisanship, and polarization in Trump's America. Annals of the American Academy of Political and Social Science, 681(1), 137-156.

Bachelard, G. (1949). Le rationalisme appliqué. Presses Universitaires de France.

Berezin, M. (2017). On the construction sites of history: Where did Donald Trump come from? American Journal of Cultural Sociology, 5(3), 322-337.

Berling, T. V. (2012). Bourdieu, international relations, and European security. Theory and Society, 41(5), 451-478.

Bobo L., Kluegel, J. R., \& Smith, R. A. (1997). Laissez-faire racism: The crystallization of a 'Kindler, Gentler' anti-black ideology. In S. A. Tuch \& J. K. Martin (Eds.), Racial attitudes in the 1990s: Continuity and change (pp. 15-44). Praeger.

Bonilla-Silva, E. (2006). Racism without racists: Color-blind racism and the persistence of racial inequality in the United States. Rowman and Littlefield.

Bourdieu, P. (1977). Outline of a theory of practice. Cambridge University Press.

Bourdieu, P. (1980). Sartre. London Review of Books, 2(22), 11-12.

Bourdieu, P. (1990). In other words. Stanford University Press.

Bourdieu, P. (1991). The political ontology of Martin Heidegger. Stanford University Press.

Bourdieu, P. (1992). Language and symbolic power. Polity Press.

Bourdieu, P. (1993). Some properties of fields. In Sociology in question (pp. 72-77). Sage.

Bourdieu, P. (1995). The rules of art. Stanford University Press.

Bourdieu, P. (1996). The state nobility. Stanford University Press.

Bourdieu, P. (2000a). Pascalian meditations. Stanford University Press.

Bourdieu, P. (2000b). Propos sur le champ politique. Presses universitaires de Lyon. 
Bourdieu, P. (2002). Masculine domination. Stanford University Press.

Bourdieu, P. (2004). Science of science and reflexivity. University of Chicago Press.

Bourdieu, P. (2005). The social structures of the economy. Polity Press.

Bourdieu, P. (2008). Sketch for a self-analysis. University of Chicago Press.

Bourdieu, P. (2017). Manet: A symbolic revolution. Polity Press.

Bourdieu, P. (2020). Habitus and field. General sociology, volume 2. Polity Press.

Bourdieu, P., \& Passeron, J.-C. (1967). Sociology and philosophy in France since 1945: Death and resurrection of a philosophy without subject. Social Research, 34(19), 162-212.

Bourdieu, P., \& Wacquant, L. (1992). Invitation to reflexive sociology. Polity Press.

Bourdieu, P., Chamboderon, J.-C., \& Passeron, J.-C. (1991). The craft of sociology. De Gruyter.

Calhoun, C. (2013). For the social history of the present: Bourdieu as historical sociologist. In P. S. Gorski (Ed.), Bourdieu and historical analysis (pp. 36-66). Duke University Press.

Chalaby, J. K. (1998). The invention of journalism. MacMillan.

Cohn, N. (1970). The pursuit of the millennium: Revolutionary millenarians and mystical anarchists of the middle ages. Revised and expanded edition. Oxford University Press.

Dezalay, Y., \& Garth, B. (2006). From the cold war to Kosovo: The rise and renewal of the field of international human rights. Annual Review of Law and Social Science, 2, 231-255.

Dromi, S. M. (2016). Soldiers of the cross: The red cross and the genesis of the humanitarian field. Sociological Theory, 34(3), 196-219.

Feagin, J. R. (2006). Systemic racism: A theory of oppression. Routledge.

Ferguson, P. P. (1998). A cultural field in the making: Gastronomy in $19^{\text {th }}$-century France. American Journal of Sociology, 104(3), 597-641.

Fowler, B. (2020). Pierre Bourdieu on social transformation, with particular reference to political and symbolic revolutions. Theory and Society, 49(3), 439-463.

Fowler, B. (2021). Writers and politics: Gisèle Sapiro's advances within the Bourdieusian sociology of the literary field. Theory and Society, online first.

Go, J. (2008). Global fields and imperial forms: Field theory and the British and American empires. Sociological Theory, 26(3), 201-229.

Go, J., \& Krause, M. (Eds.). (2016). Fielding transnationalism. Wiley.

Gorski, P. S. (2013a). Bourdieu as a theorist of change. In P. S. Gorski (Ed.), Bourdieu and historical analysis (pp. 1-15). Duke University Press.

Gorski, P. S. (2013b). Bourdieusian theory and historical analysis: Maps, mechanisms, and methods. In P. S. Gorski (Ed.), Bourdieu and historical analysis (pp. 327-366). Duke University Press.

Gorski, P. S. (2017). Why evangelicals voted for trump: A critical cultural sociology. American Journal of Cultural Sociology, 5(3), 338-354.

Hochschild, A. R. (2016). Strangers in their own land. The New Press.

Krause, M. (2011). Reporting and the transformations of the journalistic field: US news media, 18902000. Media, Culture \& Society, 33(1), 89-104.

Krause, M. (2014). The good project. University of Chicago Press.

Krause, M. (2018). How fields vary. British Journal of Sociology, 69(1), 3-22.

Kuhn, T. S. (1970). The structure of scientific revolutions. In $2^{\text {nd }}$ edition, enlarged. University of Chicago Press.

Major, B., Blodorn, A., \& Blascovich, G. M. (2018). The threat of increasing diversity: Why many white Americans support trump in the 2016 presidential election. Group Processes \& Intergroup Relations, 21(6), 931-940.

Mannheim, K. ([1928] 1952)., Competition as a cultural phenomenon. In Essays on the sociology of knowledge (pp. 191-229). Routledge.

McQuarrie, M. (2017). The revolt of the rust belt: Place and politics in the age of anger. British Journal of Sociology, 68(S1), S121-S152.

Ringer, F. (1969). The decline of the German mandarins: The German academic community, 1890-1933. Wesleyan University Press.

Sapiro, G. (2013). Structural history and crisis analysis: The literary field in France in the second world war. In P. S. Gorski (Ed.), Bourdieu and historical analysis (pp. 266-285). Duke University Press.

Sapiro, G. (2016). The metamorphosis of modes of consecration in the literary field: Academies, literary prizes, festivals. Poetics, 59(SI), 5-19.

Steinmetz, G. (2004). Odious comparisons: Incommensurability, the case study, and "small N's" in sociology. Sociological Theory, 22(3), 371-400. 
Steinmetz, G. (2009). Neo-Bourdieusian theory and the question of scientific autonomy: German sociologists and empire, 1890s-1940s. Political Power and Social Theory, 20, 71-131.

Steinmetz, G. (2011). Bourdieu, historicity, and historical sociology. Cultural Sociology, 5(1), 45-66.

Steinmetz, G. (2018). Bourdieusian field theory and the reorientation of historical sociology. In J. Sallaz \& T. Medvetz (Eds.), Oxford handbook of Pierre Bourdieu (pp. 601-628). Oxford University Press.

Strand, M. (2011). Where do classifications come from? The DSM-III, the transformation of American psychiatry, and the problem of origins in the sociology of knowledge. Theory and Society, 40(3), 273-313.

Strand, M. (2015). The genesis and structure of moral universalism: Social justice in Victorian Britain, 1834-1901. Theory and Society, 44(6), 537-573.

Walley, C. J. (2017). Trump's election and the 'white working class': What we missed. American Ethnologist, 44(2), 231-236.

Weber, Max ([1920] 1946). Religious rejections of the world and their directions. In H. H. Gerth \& C. W. Mill (Eds). From Max Weber: Essays in sociology (pp. 323-359). Oxford University Press.

Weber, M. ([1904] 1949). 'Objectivity' in social science and social policy. In E. A. Shils \& H. A. Finch (Eds.), Max Weber on the methodology of the social sciences (pp. 50-112). Free Press.

Whitehead, A. L., Perry, S. L., \& Baker, J. O. (2018). Make America Christian again: Christian nationalism and voting for Donald Trump in the 2016 presidential election. Sociology of Religion, 79(2), $147-171$.

Publisher's note Springer Nature remains neutral with regard to jurisdictional claims in published maps and institutional affiliations. 